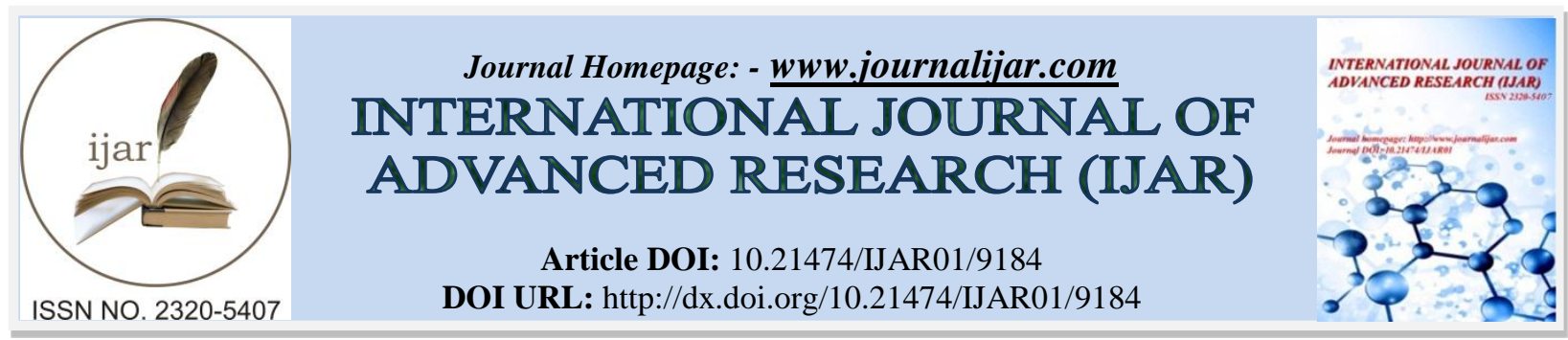

RESEARCH ARTICLE

\title{
RECENT TRENDS IN GROWTH OF HIGHER EDUCATION: A STUDY OF B.ED. COLLEGES IN PURBA AND PASCHIM MEDINIPUR DISTRICT, WEST BENGAL.
}

\author{
Mr. Arun Maity ${ }^{1}$ and Pabitra kumar Hazra ${ }^{2}$. \\ 1. Teacher-in Charge, Kharagpur Vision Academy. \\ 2. HOD, Joypur college of education.
}

\section{Manuscript Info}

Manuscript History

Received: 26 March 2019

Final Accepted: 28 April 2019

Published: May 2019

Key words:-

Growth of Higher education, Students enrolled in B.Ed., Gender distinction.

\begin{abstract}
Higher Education is one of the most important factors for short and long term economic and educational growth and development of human resource which can take responsibility for all round development including social, economical development of the country. India is currently at the stage of demographic transition where population rate is slowing down but, the trends of young people entering the labor force continues to expand. Teaching is a generous profession in our society as well as in our country. In West Bengal most of the educated people want to join this noble profession. We know that B.Ed i.e teachers' training has become mandatory in teaching profession. Here, this case study shows about the status including total enrolled students, gender distinction on the basis of category of B.Ed. colleges of Purba and Paschim Medinipur District, West Bengal during the years 2016 to 2019.
\end{abstract}

Copy Right, IJAR, 2019,. All rights reserved.

\section{Introduction:-}

Some institutions of India, such as the Indian Institutes of technology (IITs), have been globally acclaimed for their standard of education. The IITs enroll about 8000 students annually and the alumni have contributed to both the growth of the private sector and the public sectors of India. However, India has failed to produce world class universities like Harvard and Cambridge. According to the London Times Higher Education (2009)-quacquarelli Symonds (QS) World University rankings, no Indian university features among the first 100. But universities in East Asia have been included in the first hundred. Hong Kong has three, ranked at 24, 35 and 46; Singapore two ranked at 30 and 73; South Korea two ranked at 47 and 69 and Taiwan one in the 95th position. Notably, China's Tsinghai University and Peking University are ranked at 49 and 52 respectively. There is no Indian university in the rankings from 100 to 200. It is only when one moves on to the next 100 that we find the Indian Institute of Technology, Kanpur at 237; IIT Madras at 284 and the University of Delhi at 291.

A recent evaluation of universities and research institutes all over the world, conducted by a Shanghai university, has not a single Indian university in the world's top 300 while China has six. The Indian Institute of Science, Bangalore, comes in somewhere in the top 400 and IIT, Kharagpur, makes an appearance after that. Yet this decisive edge also has its shortcomings. Besides top rated universities which provide highly competitive world class education to their pupil, India is also home to many universities which have been founded with the sole objective of making easy money. UGC and other Regulatory authorities have been trying very hard to extirpate the menace of private universities which are running courses without any affiliation or recognition. Students from rural and semi 
urban background often fall prey to these institutes and colleges. Today, Knowledge is power. The more knowledge one has, the more empowered one is. According to the University Grants Commission (UGC), India needs 1500 more universities with adequate research facilities by the end of the year 2015 in order to compete in the global market.

The country lacks the critical mass in higher education. Its gross enrolment ratio (GER) is a mere 11 per cent compared to China's 20 per cent, the USA's 83 per cent and South Korea's 91 per cent. This means that in comparison to India, China has double the number of students pursuing higher education. The Eleventh Five Year Plan envisages increase in the Gross Enrolment Ratio (GER) in higher education to 15 per cent of the population in the age cohort group of 18-24 years by 2011-12. This requires a substantial increase in the number of institutions and consequently would require an adequate number of teachers for imparting education.

\section{Objective of Study}

1. To know the current status of Higher education in West Bengal.

2. To analyse the recent trends in Higher education in West Bengal.

3. To identify the status of women enrolment in higher education.

4. To identify the variation in student enrolment on the basis of category.

5. To know about the status of students enrolment from rural area and urban area.

\section{Hypothesis}

1. It has been found that the trend of female student's enrolment in B.Ed stream is higher than the male students. The study on four colleges of Purba Medinipur \& Paschim Medinipur shows that male students are losing interest in enrolling themselves in the B.ed stream of higher education. In the last three academic years (20162019) total 475 male candidates enrolled and 600 female candidates enrolled in B.ed.

2. There are more SC candidates enrolment in Purba Medinipur than Paschim Medinipur.

3. Most of the students enrolled during these years are from rural area. In the town areas girls enrolment is higher whereas in rural area male candidates enrollment is higher.

\section{Research Methodology:-}

Research methodology is descriptive and data is based on primary. For this study data and information has been collected with the help of college office. Aishe (2016-2019) Annual Status of Higher Education in States. First we selected Four (4) Colleges from both Purba Medinipur \& Paschim Medinipur district then we selected B.Ed students from these Colleges.

Table 1:-Trends in Growth of Higher Education in B.Ed colleges of Paschim Medinipur and Purba Medinipur. Number of Colleges, Students Enrolment during last four academic years.

\begin{tabular}{|c|c|c|c|}
\hline YEAR & COLLEGES & $\begin{array}{l}\text { STUDENTS } \\
\text { ENROLMENT }\end{array}$ & IN TAKE \\
\hline 2016-2018 & Kharagpur vision academy & 97 & 100 \\
\hline 2017-2019 & Kharagpur vision academy & 100 & 100 \\
\hline 2018-2020 & Kharagpur vision academy & 100 & 100 \\
\hline 2016-2018 & Institute of Education,Holdia & 100 & 100 \\
\hline 2017-2019 & Institute of Education,Holdia & 98 & 100 \\
\hline 2018-2020 & Institute of Education,Holdia & 100 & 100 \\
\hline 2016-2018 & Bankim Behari teachers training institute & 50 & 50 \\
\hline 2017-2019 & Bankim Behari teachers training institute & 48 & 50 \\
\hline 2018-2020 & Bankim Behari teachers training institute & 96 & 100 \\
\hline 2016-2018 & Vidyasagar Teachers Training institute & 94 & 100 \\
\hline 2017-2019 & Vidyasagar Teachers Training institute & 90 & 100 \\
\hline 2018-2020 & Vidyasagar Teachers Training institute & 98 & 100 \\
\hline
\end{tabular}


Table 2:-Students Enrolment during last three years (2016-18,2017-19,2018-2020) in Kharagpur vision academy.

\begin{tabular}{|l|l|l|l|l|l|l|l|}
\hline YEAR & GEN & SC & ST & OBC & MUSLIM & \multicolumn{2}{|l|}{} \\
\cline { 5 - 8 } & & & & & & MALE & FEMALE \\
\hline $2016-2018$ & 63 & 9 & 4 & 14 & 7 & 50 & 47 \\
\hline $2017-2019$ & 72 & 8 & 2 & 8 & 10 & 42 & 58 \\
\hline $2018-2020$ & $\mathbf{8 0}$ & 7 & 3 & 5 & 5 & 16 & 84 \\
\hline TOTAL & 215 & 24 & 9 & 27 & 22 & 108 & 189 \\
\hline
\end{tabular}

Table 3:-Students Enrolment During last three years ( 2016-18,2017-19,2018-2020) in Institute of Education, Haldia.

\begin{tabular}{|l|l|l|l|l|l|l|l|}
\hline YEAR & GEN & SC & ST & OBC & MUSLIM & \multicolumn{2}{|l|}{} \\
\cline { 4 - 8 } & & & & & & MALE & FEMALE \\
\hline $2016-2018$ & 68 & 29 & 1 & 1 & 1 & 24 & 76 \\
\hline $2017-2019$ & 67 & 25 & 0 & 2 & 4 & 26 & 72 \\
\hline $2018-2020$ & 69 & 25 & 2 & 4 & 0 & 19 & 81 \\
\hline TOTAL & 204 & 79 & 3 & 7 & 5 & 69 & 231 \\
\hline
\end{tabular}

Table 4:-Students Enrolment During last three years (2016-18,2017-19,2018-2020) in Bankim Behari teachers training institute,Sabang

\begin{tabular}{|c|c|c|c|c|c|c|c|}
\hline \multirow[t]{2}{*}{ YEAR } & \multirow[t]{2}{*}{ GEN } & \multirow[t]{2}{*}{ SC } & \multirow[t]{2}{*}{ ST } & \multirow[t]{2}{*}{ OBC } & \multirow[t]{2}{*}{ MUSLIM } & & \\
\hline & & & & & & MALE & FEMALE \\
\hline 2016-2018 & 29 & 19 & 1 & 1 & $\mathbf{0}$ & 39 & 11 \\
\hline 2017-2019 & 27 & 13 & 1 & 3 & 4 & 30 & 18 \\
\hline 2018-2020 & 58 & 29 & 0 & 8 & 1 & 76 & 20 \\
\hline TOTAL & 114 & 61 & 2 & 12 & 5 & 145 & 49 \\
\hline
\end{tabular}

Table 5:-Students Enrolment During last three years (2016-18, 2017-19,2018-2020) in Vidyasagar Teachers Training institute

\begin{tabular}{|l|l|l|l|l|l|l|l|}
\hline YEAR & GEN & SC & ST & OBC & MUSLIM & \multicolumn{2}{|l|}{} \\
\cline { 6 - 9 } & & & & & & MALE & FEMALE \\
\hline $2016-2018$ & 70 & 20 & 2 & 1 & 0 & 49 & 45 \\
\hline $2017-2019$ & 53 & 22 & 2 & 11 & 2 & 55 & 35 \\
\hline TOTAL & 60 & 24 & 7 & 8 & 1 & 49 & 51 \\
\hline
\end{tabular}

Table 6:-Total Student enrolment distinction on the basis of gender, Minority community groups and area.

\begin{tabular}{|c|c|c|c|c|c|c|c|c|}
\hline & GENDI & & \multirow{2}{*}{\multicolumn{4}{|c|}{ MINORITY GROUPS }} & \multirow{2}{*}{\multicolumn{2}{|c|}{ AREA }} \\
\hline & \multicolumn{2}{|c|}{ GENARAL } & & & & & & \\
\hline & MALE & FEMALE & SC & ST & OBC & MUSLIMS & Urban & Rural \\
\hline 2016-2019 & 475 & 600 & 230 & 25 & 66 & 35 & $38 \%$ & $62 \%$ \\
\hline
\end{tabular}




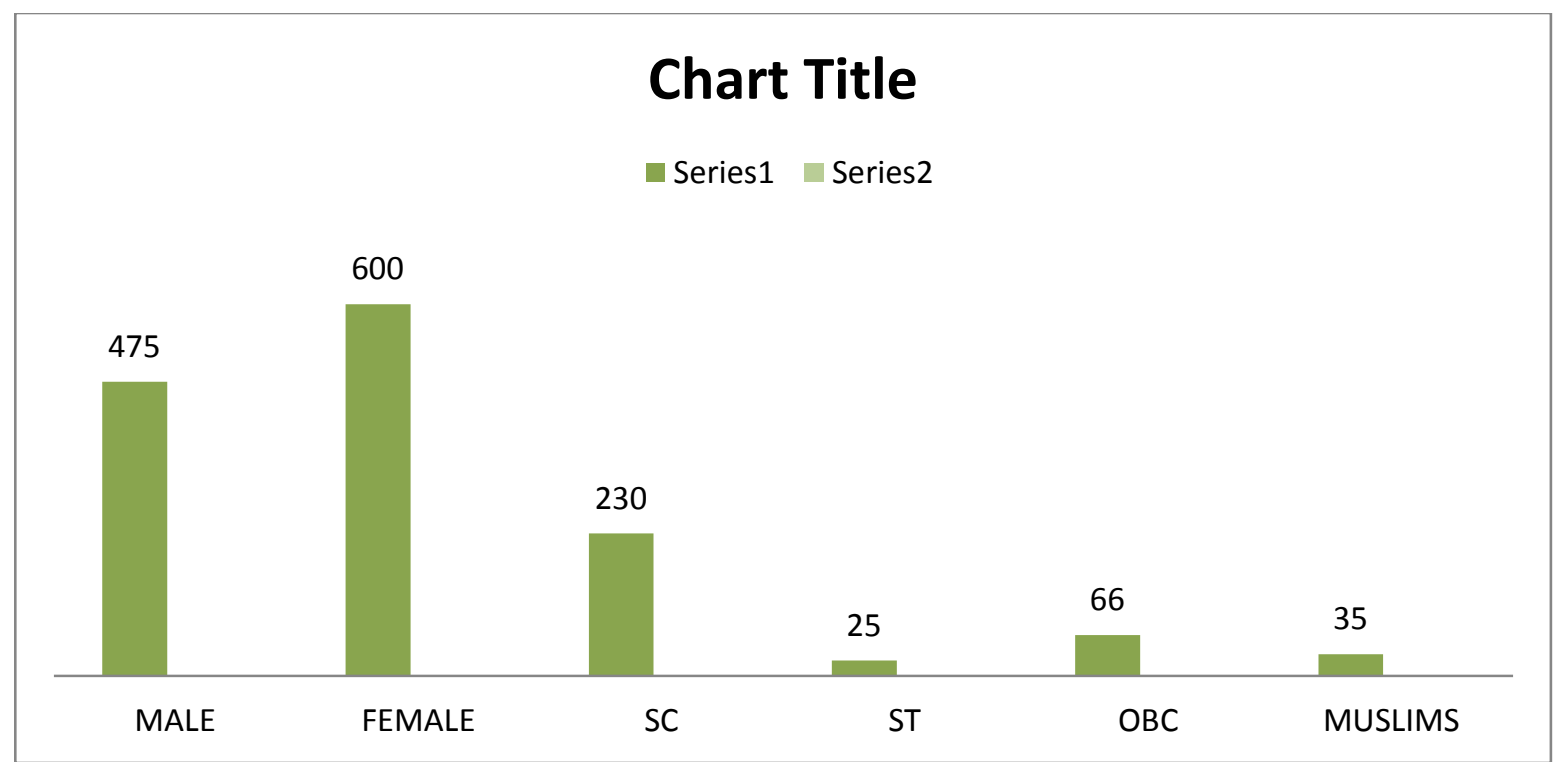

Fig 1:-Total Student enrolment distinction on the basis of gender, Minority community groups and area.

\section{Few Current Issues}

During these academic years it is evident that girls have become more interested in teaching profession. As B.ed is mandatory to become a teacher, girl's enrolment in B.ed is increasing. In recent times they think that it is a very suitable profession for firstly, it provides them security, the need not go to other state for their work.

Secondly, they consider it less time consuming which helps to keep up a balance with the family. Moreover, the govt. has made a $10 \%$ reservation bill for the girls. So there is a large scope for the girls in the govt. jobs.

Thirdly girls are getting special facilities for higher education. Govt. has launched different schemes to help the poor students for higher studies.

Male candidates are losing their interest in B.ed for they don't think it suitable for them. But male students from rural areas are getting more interested in B.ed. And both male \&female students belonging to muslim community enrolment is increasing day by day.

\section{Conclusion:-}

In recent times the trend has been changed girls are coming forward to join teachership as a result then are getting interested to B.Ed people of rural areas also become conscious and are trying to take part in the nation building. The government in also trying their best to spread education among all specially for girls and in rural areas . Different schemes have been launched and money colleges are set up so that each and every one can have a scope for B.Ed .UGC \& NCTE are also trying to provide all scopes for B.Ed to also that the traditional system get changed. Above all to overcome the challenges we all should come forward and only then we can have developed nation.

\section{References:-}

1. Agarwal, P. (2006). "Higher Education in India: The Need for Change." ICRIER Working Paper, Indian Council for Research on International Economic Relations: No. 180.

2. Chakraborty,A (2009) Determinants of Participation in higher education and Chice of Disciplines :Evidence from Urban and Rural Indian Youth ,South Asia Economics Journal ,10.2 371-402.

3. CABE Committee. (2005). Report of the Central Advisory Board of Education (CABE)Committee on Financing of Higher and Technical Education. Government ofIndia. June 2005.-first Century. UNSECO Publishing,Paris

4. Dandapat,A.K. \& Sengupta,(2012) Gender and social Equality in :a Case Study of a rural University .Journal of Educational Planning And Administration .

5. Dougherty.S and Herd,R (2008)"Improving Human capital Formation in India", OEDC Economics department Working papers,No.625.doi:10.1787/241005853765. 
6. Dill, D. D. (1999) Academic Accountability and University Adaptation: The Architectureof an Academic Learning Organization. Higher Education, 38(2): 127-154.

7. Frank, R. (2001). Higher Education: the ultimate Winner-Take-All Market?. In Devlin

8. Filmer,D and Pritchett, L.(1999)Educational Enrolment and Attainment in India: Household Wealth ,Gender, Villege , and State Effects. Wasington D.C :The World Bank.

9. Ficci. (2011). "private SECTOR PARTICIPATION IN indian HIGHER EDUCATION," ficci HIGHEREDUCATION SUMMIT 2011, ernst \& young pvt. Ltd., Kolkata

10. Reddy,G.L \&.Anuradha,V.(2013) . Higher education for persons with Disabilites in India problems and prospects.

11. Stella, a. (2002). "external quality assurance IN indian higher education: CASE STUDY OF then ational assessment AND accreditation council." International institute FOR educationPlanning, unesco. Paris.

12. UGC. (2012). "Higher Education in India at a glance." UGC. February. 